\title{
A Place to Learn and Work: Yuendumu Learning Centre
}

\begin{tabular}{c|c} 
Samantha Disbray & Ros Bauer \\
$\begin{array}{c}\text { CRC for Remote Economic Participation \& } \\
\text { Charles Darwin University } \\
\text { samantha.disbray@cdu.edu.au }\end{array}$ & CRC for Remote Economic Participation \& \\
& Adult Literacy Services \\
\hline
\end{tabular}

Keywords: adult education; adult learning; community education; learning centres; Indigenous Australia

\begin{abstract}
In recent years, Community Learning Centres have emerged as a new community partnership model providing adult education in remote Indigenous communities in Australia, and in four Warlpiri Communities, funded locally by the Warlpiri Education and Training Trust. They are showing success by meeting local individual and community adult learning aspirations, and pathways to employment. This paper presents a reflective case-study of one such centre, the Warlpiri Triangle College Adult Learning Centre at Yuendumu in Central Australia. The study draws on an account of learning that is broad, diverse and situated in meaningful activity, which is responsive to the social, economic and learning needs of remote settings like Yuendumu. It draws out key elements operating at the Learning Centre in Yuendumu that allow for responsive and sustainable learning and training, with important implications for policy development in community development, education, training and employment in remote Australia.
\end{abstract}

\section{Introduction: Adult learning in Australian remote Indigenous communities \& the Yuendumu Learning Centre}

A significant body of qualitative research has identified non-formal learning and informal learning ${ }^{1}$ as important means to engage or re-engage learners with poor literacy and numeracy skills, negative experiences of schooling and/or little confidence in, or little need for formal learning, and serve a number of community and individual goals, such as pathways into employment (Adult Learning Australia, 2014, pp. 4-5; Beddie \& Halliday-Wynes, 2009; Birch, Kenyon, Koshy, \& Wills-Johnson, 2003; Clemans, 2010; Kral \& Schwab, 2012). In remote Indigenous contexts in the Northern Territory, secondary education completion rates are low, as are post-primary academic achievement rates (Wilson, 2013, p. 22 and p. 139). While formal training suits the employment and learning needs of some adults in these communities, non-formal learning programs for young people and adults emerge as both important and effective in a number of recent studies (Guenther, McRae-Williams, \& Kilgariff, 2014; Kral \& Heath, 2013; Kral \& Schwab, 2012; Kral \& Schwab, to appear; Shaw, 2015). A common thread through the literature is their scope to offer meaningful and responsive models of learning, education and training that resonate with local realities and meet local aspirations.

1. We use non-formal learning to refer to any intentional unaccredited learning, broadly following Adult Learning Australia (2014, p. 5). 
In the past, an extensive array of adult education programs with locally based educators working in the community through the Northern Territory Open College, and later, the Community Education Centres, provided the opportunity for post-school learners to undertake basic education, along with formal work-related programs (Arnott, 2003; Collins, 1999, p. 112; Northern Territory Department of Education, 1987). However, in the late 1980s, in response to broader global changes, Australia introduced the National Training Reform Agenda (1987-1996). The development of a Standards Framework for vocational education and training credentials was among the initiatives in the Australian Government's effort to reform the vocational education and training system and its linkages to the workplace. This, along with the shift from Commonwealth delivery of education provision to Territory government and subsequent funding arrangements, led to a more formalised approach not only to school to work transitions, but to adult learning more generally (Adult Learning Australia, 2014; Arnott, 2003; Collins, 1999; Kral, 2010). The prioritisation of block-delivery Vocational Education and Training (VET) programs in remote communities by drive-in, drive out trainers has resulted in a lack of co-ordination of learning and training programs (Collins, 1999, p. 112). In 2007, Young, Guenther \& Boyle observed adult learning programs are characterised by low completion rates in formal training programs, and 'a significant misalignment between the content and delivery models of VET and the prior skills, educational demands and aspirations of Indigenous people' (p. 7).

The case study presented in this paper illustrates how one community learning centre facilitated meaningful learning and the achievement of a range of local goals, including but not exclusively, pathways directly to employment. Carried out by Samantha Disbray, Charles Darwin University and the Remote Education Systems ${ }^{2}$ researcher, and adult educator Ros Bauer, it explores the establishment and operation of the Warlpiri Triangle College Adult Learning Centre at Yuendumu (referred to locally and forthwith as 'the Learning Centre'). It considers the ways in which the Learning Centre sought to provide a place with a flexible and responsive approach, integrate local priorities and authority structures, and provide some co-ordination of training and learning across the community. The analysis that follows, identifies key elements of this community learning program. The appraisal of these allows for broader consideration of such community education programs in remote Aboriginal contexts, which can inform similar projects and should be incorporated into future education, training and employment policy.

\section{Questioning assumptions}

Conventional wisdom, at least as portrayed in the media, suggests attendance at school, completing year 12 and gaining certificates is the key to improving economic participation. These assumptions, which may hold true generally in non-remote contexts, need to be carefully considered, particularly in the challenges governments have faced over decades in affecting change in remote communities. In one study, the Remote Education Systems (RES) project investigated the assumed link between school attendance and academic achievement (Guenther, 2013). It found student attendance had little impact on NAPLAN scores in remote schools with more than 80 per cent Aboriginal and Torres Strait Islander student enrolment. In effect, coming to school did not achieve the standard measure of school success. Yet, the focus of education policy and systems for very remote education is on attendance, along with teachers and teaching to overcome the 'education failure' (Guenther, 2015) and closing gaps (Abbott, 2014). However, the situation is more complex and other considerations are at play, significant to education and training policy.

2. The Remote Education Systems project is part of the Co-operative Research Centre - Remote Economic Participation, http://crc-rep.com/remote-education-systems. 
The work of education anthropologists and sociologists has shown that behind the apparently natural uptake and success of schooling and seamless transition to employment lie specific processes and practices of acquisition, socialisation to and reproduction of habits, behaviours and dispositions. These underpin the acquisition of literacy, schooling and successful transition to work (Barton, Hamilton, \& Ivanic, 2000; Heath, 1991; Kral \& Schwab, to appear; Schwab, 1998; Watson-Gegeo, 1992). However, in remote Indigenous societies, the institution of Western schooling was introduced very recently (Campbell \& Proctor, 2014; Price, 2012) and there has been little time for remote communities to reap the promised returns, or for intergenerational reproduction of the associated learning, literacy and work practices and routines (Guenther, Disbray, \& Osborne, 2014; Kral, 2012; Kral \& Falk, 2004; Kral \& Schwab, 2009); and the overarching goals and aspirations that drive these orientations and practices in day to day life (Guenther \& Bat, 2013; Osborne \& Guenther, 2013).

Still education, learning and employment are valued for the achievement of personally and socially meaningful goals in remote Indigenous communities (Kral \& Falk, 2004). In their synthesis of the purposes and value of education, Fordham and Schwab $(2007$, p. 33) note the following valued outcomes:

- developing basic literacy and numeracy skills

- a means for gaining employment

- $\quad$ providing an opportunity to develop the necessary skills to deal with the non-Indigenous agencies, services and culture

- $\quad$ ensuring the continuity of their own culture in more contemporary times

- improving the well-being of the community.

In 2014, the Australian Government announced its Indigenous Advancement Strategy, which set five priority areas: Jobs, Land and Economy; Children and Schooling; Safety and Wellbeing; Culture and Capability; and Remote Australia Strategies. In early 2015 the first round of successful applicants were announced. Despite the focus on remote Australia, there is still a risk that programs will be designed with mainstream outcomes, unaligned to the daily realities and goals of communities, resulting in inbuilt failure. Outcomes for the five areas include a continued strong focus on education, with children and school attendance at one end, and training for young people and adults for employment at the other. In 2015, the White paper on Developing Northern Australia was released (Australian Government, 2015), exploring policy and development directions relevant to remote Aboriginal Australia. It acknowledges the economic value of Aboriginal land and the potential for the 'application of traditional Indigenous cultural knowledge to improve environmental understanding, inform ecological management and create new technologies [... and] to strengthen the economic future of northern Australia' (Australian Government, 2015, p. 26 and p. 135), yet the mechanisms for knowledge transmission reflected in the document are restricted to formal education and training.

This paper seeks to show that a community-based learning model the Community Learning Centre offers a site for adults to seek and undertake meaningful and purposeful learning, to fulfil a range of goals (including employment) embedded in the social, cultural and economic dynamics of their community. To do so, we explore adult learning and the emergence of community learning centres in remote Indigenous communities by providing the case study of the Learning Centre at Yuendumu. The Centre operated for just one year, 2013. In 2014, the new Jaru Learning Centre opened and assumed responsibility for adult learning in Yuendumu. It is the result of a tripartite partnership between the Warlpiri Education and Training Trust, the Warlpiri Youth Development Aboriginal Corporation (WYDAC) and Batchelor Institute of Indigenous Tertiary Education, the centre's operator (Kelly, 2015, p. 11). Our study focuses on the predecessor. 
Recent research has set the emergence of community learning centres in a broader framework of learning theory (Kral \& Heath, 2013; Kral \& Schwab, 2012; Kral \& Schwab, 2009, to appear). We discuss this research to position the Yuendumu Learning Centre within a broader context. We then detail our case study and discuss the centre's strengths, guided by Kral and Schwab's 'design principles' (2012, pp. 58-92) and 'key elements' (to appear, pp. 10-13). We conclude the paper first by considering further potential of this community-based model, and then by looking at some of the challenges to community learning centres. In particular, we propose the community learning centre model, with thoughtful planning and implementation, could be expanded to provide flexible secondary programs for young people, or play a strong collaborative role in such programs. This is particularly important as the Northern Territory Government, following trends in Cape York, Queensland retreat from provision of secondary education in remote Indigenous communities (Northern Territory Government, 2015).

\section{Our method}

The research project began in July 2013 through a partnership between the then Yuendumu Learning Centre (YLC) Co-ordinator Ros Bauer and CRC-REP Remote Education Systems project researcher, Samantha Disbray, to document the activities and outcomes of the Learning Centre. The research arises from our position as qualitative researchers seeking to understand the dynamics of adult learning in a remote community. Our way of working is interpretive, participatory and constructivist (Lincoln, Lynham, \& Guba, 2011). We draw on our critical reflexive professional practices through observations within the context of our work (see Patton, 2015, Module 50; Van Manen, 1997) and this reflective process began in 2012 before the Centre opened, while we both were employed with the Northern Territory Department of Education (NT DoE); Ros as adult language literacy and numeracy practitioner, and then the YLC Co-ordinator, and Samantha as the NT DoE linguist working with the four Warlpiri community schools. Reflections were teased out at a workshop held by Batchelor Institute in early 2013 , led by Inge Kral and Jerry Schwab, which also raised our understanding of an ethnographic method of observation, artefact collection and participatory practice, and we have used a range of research methods to develop this chapter.

Our respective positions allowed long-term participant observation; on going by Ros Bauer throughout 2013 and since in a range of roles. Once Samantha joined the RES project, targeted observations began, and were carried out between July-December 2013. Throughout this time both kept notes of discussions, brainstorms and observations. In 2014, Samantha undertook in-depth reflective interviews with the Warlpiri staff and community members who used the Learning Centre. We are grateful to these people for their participation. We also draw on learning artefacts, such as texts, photographs and notes gathered throughout. Data generated at the centre, such as activities undertaken and services provided to other organisations in the community provide a further source of information.

\section{Background}

\section{Adult learning and community learning centres}

The recent emergence of community learning centres in remote Indigenous communities can be set in a broader framework of learning theory and learning contexts globally, where learning becomes 'situated, reciprocal and distributed' in what Gutiérrez (2008, p. 159) describes as a 'Third Space'. Within this frame of reference, learning is seen not just as a formalised vehicle for economic gain, as Human Capital Theory (Becker, 1993) might suggest, but a powerful 
and transformative opportunity for individual, group and social change (Lave, 2011; Mezirow, 2012). The study of everyday cognition and cultural development has investigated how people learn across social settings, activities, life spans and pursuits (Gutierrez \& Rogoff, 2003). This work recognises the central role of the home and community as spaces for non-formal learning and the development of 'communities of practice' (Wenger, 1998), which surround and support learning (Lave, 2011; Rogoff, Paradise, Arauz, Correa-Chavez \& Angelillo, 2003). Emphasising the breadth of learning experience throughout life, researchers from the Learning in Informal and Formal Environments (LIFE) Center (University of Washington) identified the following principles to best inform the development of learning programs:

- $\quad$ Learning is situated in broad socio-economic and historical contexts and is mediated by local cultural practices and perspectives.

- Learning takes place not only in school but also in the multiple contexts and valued practices of everyday lives across the life span.

- All learners need multiple sources of support from a variety of institutions to promote their personal and intellectual development.

- Learning is facilitated when learners are encouraged to use their home and community language resources as a basis for expanding their linguistic repertoires. (Banks et al., 2007, p. 15)

These insights have arisen from and fed into a rich and growing global research base of youthbased and community models, which foster and spark learning for marginalised learners (for example Cushman \& Emmons, 2002; Hull, 2003). Heath and Street draw common threads in community-based learning projects, identifying among their strengths 'freedoms of time, space, activity and authority that schools as institutions rarely provide' (Heath \& Street, 2008, p. 5).

In Indigenous communities of remote Australia, the work of Kral, Schwab and Heath has documented the emergence of community learning spaces (Kral \& Heath, 2013; Kral \& Schwab, 2012; Kral \& Schwab, 2009, to appear). Focussing on youth learning they document 'productive activity that builds on school learning - or makes up for what was not learned at school - and develops the kinds of communication, technological and organisational learning skills required for successful futures for Indigenous youth in the twenty first century' (2012, p. 19). Further research in northern Australia has pointed to the blurring of boundaries between formal, nonformal and informal adult learning that occurs in communities (Guenther, Falk, Arnott, Lucardie \& Spiers, 2008; McRae-Williams, 2014), including the Warlpiri communities (Shaw, 2015), and in the past (Arnott, 2003). These conceptualisations informed the development of the Learning Centre at Yuendumu, which we will explore in the case study.

\section{Yuendumu}

Standing at the opening in the chain mesh fence by the petrol bowser, I look out and see Betty ${ }^{3}$ making her way along the red dirt road in the rising morning heat, between the store and the school. She's hauling a mass of leopard print blankets, she's moving 'camp'. Some noisy kids, little and big, dawdle by, clunking the double school gates, camp dogs slipping in quietly behind them. Jangala walks over, heads into the Learning Centre for a chat and 'nalija' - cup of tea. I follow him through the wide, plastic fly-proof strips at the store, into the windowless room off to the left, where Nerida is showing a group of women how to set up an I-Pad. (Ros Bauer, reflection) 
Yuendumu is a remote Indigenous community $300 \mathrm{~km}$ north west of Alice Springs in the Northern Territory. Between 500 and 900 Aboriginal people live in the town, along with 100 non-Aboriginal people (Musharbash, 2008, p. 19). Yuendumu is a Warlpiri community, one of four communities in the Tanami region. The other communities are Nyirrpi, Willowra and Lajamanu. People here have a strong sense of local and regional Warlpiri identity. Warlpiri is spoken in most everyday interactions, though there are high levels of bi- and multilingualism. Even the oldest residents speak at least some English, though it is very much a second language, largely for communication with those outside of their speech community.

Warlpiri have long shown their commitment to their language and identity through, for instance, the local media association and bilingual education programs (Disbray, 2014). Pintupi, Anmatjerre, Warlpiri Media (PAW Media, still widely known by its previous name Warlpiri Media) has an impressive output of Warlpiri (and other) language products, as well as a radio broadcaster, reflecting masterful adoption of new technology for communication, selfexpression and contemporary identity. Warlpiri have also been very proactive in supporting education regionally, establishing a trust negotiated from royalty payments, the Warlpiri Education and Training Trust, which funds a range of learning and training initiatives in the four communities (Warlpiri Education and Training Trust, 2013).

Yuendumu was established as reserve in the late 1940s and Warlpiri have a relatively short history of intensive contact with non-Aboriginal people, language and culture. According to anthropologist Yasmine Musharbash contemporary practice is deeply informed by traditional Warlpiri identity and guided by the core values of immediacy, mobility and intimacy (Musharbash, 2008). For many Warlpiri adults, engagement in community civic matters has been intensive, with past and on-going negotiations for their Land Claims, Community Council, mining agreements and royalty associations, Indigenous Protected Areas and numerous government and non-government projects and programs, always requiring community consultation. There are a number of organisations in the town, some local, some provided from outside, with many Yuendumu residents involved as steering committee and board members or staff. These organisations include the Warlpiri Youth Development Aboriginal Corporation (WYDAC) with its youth highly successful diversion program Jaru Pirrjidi (Stojanovski, 2011) and informal learning program (Shaw, 2015); an arts centre, Warlu-kurlangu; Mampu Maninja-kurlangu Jarlu Patu-ku Aboriginal Corporation (Yuendumu Old Peoples Programme; a Women's Centre; Yantarnili Ngurjujarrinjaku (Health Clinic); Central Land Council office with a Ranger Program; the three stores; an Early Childhood Centre; and Yuendumu School. These organisations are the key employers of Warlpiri people, and 2011 census data show eighty per cent of the Indigenous labour force at Yuendumu is employed, at least part-time. On the other hand, the employment rate among the non-Indigenous population is ninety-five per cent. This civic life, along with family commitments, sports weekends, trips to town (Alice Springs and beyond) and the many pressures associated with decades of rapid social change, such as ill-health, poverty, incarceration and a regular cycle of sorry business, characterise Warlpiri community life.

\section{Adult education in the NT and Warlpiri communities}

Adult education has been provided in the NT since the 1950's (Berzins \& Loveday, 1999; Frawley, 2003). In the mid-970s the Commonwealth Teaching Service took responsibility for education in the NT and, in 1975, appointed a Senior Education Advisor in Aboriginal Adult Education, along with 16 senior teachers located in communities. The following year Aboriginal Assistant Adult Educators were added (Arnott, 2003, pp. 45-46). In 1979, the NT Government assumed responsibility for education, establishing a TAFE branch and, through to the late 1980's, further developed the workforce dedicated to community adult education, increasing the number of locally based educators and adding a number of travelling specialist lecturers and funds for part-time teachers (Arnott, 2003, p. 46). According to Arnott (2003), citing Bond (1977), 
the objectives were oriented towards individual and community development, and clearly responsive to locally defined needs. In 1984, regional TAFE staff developed a checklist for adult educators which listed: Aboriginal initiative, management and control; high relevance of the course to the learners; flexibility within the program; good relationships between instructor and participants, among other characteristics (Arnott, 2003, p. 49). By 1986, the responsibility for community-based adult education rested with the newly established Northern Territory Open College (NTOC) (Frawley, 2003).

The development of adult education was responsive to the broader context of politicisation and self-determination across Aboriginal Australia of this period. The establishment of 'Aboriginal organisations' such as community-controlled health services, housing authorities, legal services and media organisations were means for Aboriginal people to assert their Indigenous identity and aspirations for community control. Adult education was critical for Aboriginal people to take active roles in these enterprises. The NT bilingual program, including the programs in the Warlpiri schools, was a further vehicle for adult learning, employment and critical reflection (Walton \& Eggington, 1990). Indeed Yuendumu, as one of the first schools in the bilingual program was well-serviced in adult education and teacher training specifically from the early 1980's, with a locally based Batchelor Institute educator (then Batchelor College) and a school based mentor. In 1987, the Northern Territory Education Department established a program of Community Education Centres (CEC), which combined Adult Education and post-primary resources, to provide accredited courses including general studies and TAFE Certificate award courses 'relevant to community self-management, enterprise development and self-sufficiency' and bridging to further learning (Northern Territory Department of Education, 1987, p. 1). Yuendumu was among the first eight trial sites for the program, and under it, was assigned community educators and instructors. The CEC program ended in the mid 2000's, around the same time the Batchelor Institute lecturer based at Yuendumu was relocated. Until the establishment of the Learning Centre at Yuendumu and the WETT Community Learning Centres at the other communities, locally based lecturers have been ad hoc and temporary.

In 2005 a group of Warlpiri educators from the four communities working with the Central Land Council negotiated with Newmont mining company to establish the Warlpiri Education and Training Trust (WETT), which funds five project areas, one of which is the Community Learning Centre Program (Kelly, 2011, 2015; Schwab, 2006). These educators were involved in adult education in the 1980's and so have experience of the adult community learning of previous decades. In partnership with the Central Land Council and Batchelor Institute, WETT Learning Centres opened at Nyirrpi and Lajamanu in 2010, at Willowra 2013, and the Jaru Learning Centre, in partnership with the Warlpiri Youth Development Aboriginal Corporation at Yuendumu in 2014. These centres support formal and non-formal learning, as well as community-driven intergenerational projects. The learning centres are guided by a local reference group as well as the WETT Advisory Committee, drawing on local authority structures.

\section{Adult education at Yuendumu}

At Yuendumu, Warlpiri people work in the community initiatives and workplaces mentioned earlier. Training is frequently integrated with, rather than a pre-requisite for these employment opportunities. Training often involves a mix of on-the-job learning and formal attainment of vocational certificates. When the Learning Centre opened, a range of training providers were offering accredited training in Yuendumu, generally on a workshop delivery basis, with 'drive-in, drive-out' trainers. Ros Bauer came to work in Yuendumu in June 2012 as an adult educator on a Workplace English Language Literacy (WELL) project with the Warlpiri Youth Development Aboriginal Corporation (WYDAC). Yuendumu community did not have a WETT Learning Centre or any permanent adult learning or adult language literacy numeracy (LLN) provision at the time. WYDAC and the regional Northern Territory Education Department 
principal ${ }^{4}$ had identified the need for this service for its workforce and the broader community. Ros was based at WYDAC as a LLN educator.

The WYDAC service is well used by the community. Its in-house youth worker training is a very successful learning program, with significant well-being and employment outcomes (Shaw, 2015). People come to WYDAC for all manner of purposes, many involving learning, and accessing or requesting support was an established facet of service. Prior to the establishment of the Learning Centre, there was a need for learning support directly related to vocational or formal training, but also for the development of personal literacies; support with banking, resumes, personal technologies, and responding to letters. Some people liked to be in the space, did not have specific goals, but rather an interest in getting involved. As Ros became the 'go-to' person learning increasingly took place in the 'community classroom' - in a front yard, under a tree, at the basketball court, or sitting in the back of a 'troop carrier' (four wheel drive vehicle) - wherever people felt comfortable and whenever the service was required.

It quickly became clear that some young local women who showed interest in working with Ros could be mentored to support the literacy demands of many of these learning interactions, such as the reading and writing requirements of document applications, technology for banking, music downloads, and phone and i-Pad activation. The idea of community literacy tutors came into being. The local Social Club committee offered the use of their storeroom in one of the local stores as a learning space. Various other community partners contributed computers, furniture and other useful hardware. With this support and a small amount of funding from the College to employ the tutors, the Learning Centre was born. WYDAC Youth Workers and the Mental Health Worker also spent a proportion of their work time as tutors, providing a larger pool of community literacy tutors. Other organisations such as Waltja Money Mob and PAW Media contributed special expertise in their industry roles.

\section{The Learning Centre - A place for learning}

The Learning Centre opened in February 2013. That month there were 19 learner contacts and by September this had increased to 171 people, and a total of 870 over the course of the year. The Centre opened all day on week days, and at staggered times on weekends. Independent of the structure of a strict timetable, people could access support in sync with other community, family and cultural commitments.

There wasn't a place like that before. There was only school for kids, but not for adults. It was a good place for people to come to have a cuppa, too. To tell stories, Yapa stories. [Older men] Freddie came, and Tom loved it, Oli, Mr. F and Gardner. They could listen to old time stories, Yapa stories. My father was proud when I got this job.

Some young ladies came, our age, for work, but we could talk about [events] at camp ${ }^{5}$, like news you know. Sometimes they wanted to know what the new rules were for Centrelink or for [school] attendance, and we could talk about that. (Reflections from two of the young community literacy tutors)

It was a place for learning, formal and informal, and a place that recognized and realized intergenerational practices and values related to learning, work and sociality.

4. At the time, the Warlpiri schools administration was under a college model, the 'Warlpiri Triangle College', overseen by a single Principal, Darrel Fowler, who was responsible for Early-Childhood to post-schooling provision in the four communities. This Northern Territory Education Department initiative, reminiscent of the CEC model, was short-lived, and ended in 2013. 


\section{Non-formal learning opportunities}

Non-formal learning was central and the cycle of engagement can be best described through a learning model that set out to address social, emotional, intellectual and aspirational learning. For some, the cycle might begin with as engagement for social purposes. As the participant began to feel more confident in the space, they sought support for personal and community literacies. This includes tasks such as setting up and using electronic services for banking, applying for a driver's license or activating i-Pads. Often it acted as a springboard, as taking part in a learning interaction involving a personal literacy lead to other connections. With the confidence to come in and take part in one interaction, people often identified more learning needs and took part in more activities.

\section{Formal learning opportunities}

Accredited training was provided through the Learning Centre to a range of groups. The senior girls class from Yuendumu School completed a skills set from Certificate I in Education and Skills Development. They undertook a project-based course to explore their understanding of learning styles and their own skills in relation to job roles in the community. As part of the course each participant constructed a profile of herself as a learner using italk ${ }^{\mathrm{TM} 6}$ libraries software to import local images and self-generated audio, each creating a multimedia and multilingual product. The training was auspiced by Batchelor Institute, but delivered by the Ros and supported by the tutors. The tutors completed the course themselves alongside other learners, reflecting on their own learning styles, and, as learning facilitators. With this experience and expertise, they led the other young women through the course materials using Warlpiri language to clarify key concepts and consolidate learning.

We did the certificate, work about how you learn and how other people learn. Then we could tutor them. We helped them with writing in the book and making the italk project. They liked italk. They got experience. One young girl got job straight away [at the old people's centre]. Old people need to get looked after. The Learning Centre was giving her ideas. Young people need to work, not stay at home. (Reflection from a community tutor)

The Learning Centre also brokered partnerships for accredited vocational training for trainees. One group enrolled in a Building \& Construction Pathways certificate course were working on the local housing refurbishment project. The collaboration enriched the training by providing targeted language, literacy and numeracy learning for speakers of English as an Additional Language. Participants were supported in the classroom sessions by the LLN educator (Ros Bauer), the tutors and with the VET trainer undertook practical tasks. This allowed a combination of individualised and applied learning approaches.

\section{Community tutors as learners and educators}

The tutors held multiple roles, as learners and learning facilitators, kin, peers and community members, and as employees. The three key tutors who took up the roles, had followed learning/ working trajectories common in their communities. The three were close kin and of similar ages, and had moved through their education and employment lives as a cohort. Together they

6. italk $\mathrm{K}^{\mathrm{TM}}$ is bi-lingual story making software that makes it easy to create and listen to stories in two languages. 
had completed primary school and some secondary schooling in the community and gone briefly to boarding school before leaving or attaining formal qualifications. They had undertaken some work in the community (in aged care), some relevant training at Batchelor Institute and started their own families. This shared history, and the core Warlpiri value of intimacy, expressed in the importance of being in company, or 'marlpa' (Musharbash, 2008, p. 44) was reflected in the way the tutors worked, collaborated and negotiated as a group in the Learning Centre.

In the Learning Centre these three young women continued to work together in a working and learning environment that supported and benefited from this dynamic. The Learning Centre was a safe learning place, where adults could learn together and from each other. Two of the tutors reflected on their own learning and problem solving ( $G \& N$ with Interviewer $-\mathrm{I}$ ):

\section{G: Ros helped sometimes, sometimes we got along ourselves.}

$N$ : With each other, worked it out together, to work out ourself, we tried a lot things a little bit.

\section{l: Were you worried about trying things out?}

G: No, it always worked.

\section{N: We could ask someone, Ros or another Kardiya or a Yapa person.}

In the learning interactions the tutors managed with community members using the Centre, to draw on and build their language, literacy and knowledge funds as bilinguals. For instance, supporting a learner to complete a form in English involved reading through the form together, discussing the meaning of individual words, phrases and purposes in Warlpiri and re-iterating the key or novel terms in English. In such interactions, there were often significant learning opportunities for English language and literacy and interaction with English texts, their purpose and meaning. This 'third space' (Gutiérrez, 2008), where the communicative repertoires of the tutors and learners is drawn and built on, is only opened up in interactions between bilinguals.

The Centre presented other opportunities for developing communication skills. The tutors also became skilled in developing video tutorials, filming and talking through common procedures, such as logging in to a service, changing a password and other technological tasks. The tutors' confidence as learners, learning facilitators and employees grew over the course of the year. Their active role in professional gatherings was important in this. In July 2013 they attended the Warlpiri Triangle Workshop, an annual professional learning event for school staff across the region. Later in the year, they attended the annual conference of the Australian Council of Adult Literacy in Sydney and gave a presentation about their work in the Learning Centre.

Their work hours were part time and flexible to allow for attention to family and community commitments. At the beginning of each week a planning meeting was held and each person wrote the hours they were prepared to work that week on a white board, with the goal that at least two of the three were at the Centre for the busiest times.

\section{Spread the learning}

One final set of learners is important to discuss. Much of the vocational training was being delivered through an imported 'drive-in drive-out' workforce. It became clear that a more strategic approach could harness the skills of many staff already working in the community's main industries, media and community services. Those working in the community already had strong relationships with local people and could work more flexibly in response to the ebb and flow of community life. They were living in Yuendumu and, in the case of non-Indigenous staff, 
mindful of their own reliance on Warlpiri people in the community to orient and guide them on local protocols and social dynamics required to succeed in their workplaces. By developing their training skills with a specific focus on supporting language and literacy, the incidental, on-the-job training they were already providing could be formalised. It was also a chance for Warlpiri and non-local staff to reflect together on the Two-Way nature of learning in the workplace and in the community.

Overall, this heightened everyone's sense of workplaces as places to learn and provided pathways that accommodate learner identities, skills and dispositions. Thus, face-to-face training for a Certificate IV in Workplace Training and Assessment was provided in Alice Springs to a number of employees from the school, WYDAC, the Learning Centre and PAW Media, with weekly study sessions at the Learning Centre to complete assessments, contextualised for delivery to diverse learners. The participants completed the course and acknowledged having a much clearer understanding of how to identify the language and literacy challenges in training material and to support the language and literacy needs of the learners they were working with at Yuendumu.

\section{Approaches to Learning}

Learning approaches reflected the principles identified by the LIFE group discussed above, as situated in the social context of Yuendumu and responsive to local skills sets, aspirations and opportunities. For Ros, this demanded an instructive flexibility, as a sense of 'being in the world' (Musharbash, 2008), as the logic of the push and pull of daily life is not immediately clear to the non-local colleague in this cross-cultural setting (akin to 'rhythms of the community' in Arnott, 2003, p. 57). Actively seeking to understand and respond on this logic was crucial and supported opportunities for learning, for Ros, tutors and a wide and diverse network of learners in Yuendumu.

In addition, as an LLN educator Ros's approach to learning interactions with the tutors, other trainers and learners drew on principles of adult learning (Knowles, 1980), an awareness of (many of the) learners' needs as users of English as an additional language, and these came together in the conception of multi-literacies (Cope \& Kalantzis, 2000), which focuses on message, meaning and media. And finally, use and mastery of technology, known to contribute to literacy development as well as social capital gains (Boyle \& Wallace, 2008), were central to most learning interactions at the Learning Centre.

From an adult literacy perspective, I was very explicit in teaching learning awareness with a focus on practical strategies, working towards higher levels of reading, writing and numeracy. I drew on my knowledge of TESOL to target the learning at a level above the learner's current competence. This was especially evident in the way that the tutors navigated the digital environment, providing a means to extend the literacies they already had. Also the Learning Centre energy and culture was welcoming, unstructured, learner centred and free from anxiety or stress, creating optimal conditions for learning. I had high expectations of the tutors and nurturing their own self-belief was crucial to their achievement. You could say that it was skills based approach, sitting within a broader framework of social practice. (Ros Bauer, Reflection)

Ros was recognised for her expertise and innovation as she received the 2013 Language, Literacy and Numeracy (LLN) Practice Award for her work at the Learning Centre (Australian Training Awards, 2013). 


\section{Discussion}

In their research focussing on youth learning, Kral and Schwab have discussed 'design principles' for learning spaces in remote Australia (2012, p. 58-92) and later, from a set of case studies of four Learning Community Centres co-ordinated by Batchelor Institute (to appear, p.10-13) they identify 'key elements', positing that a Learning Centre is:

- A vibrant, community-based learning facility that brings adults of all ages together, to help each other, to work together and to learn together.

- A place where individual and community development aspirations can be achieved.

- A place where there is a commitment to local ownership and management.

- A place where there is co-ordination of informal and formal learning, individual learning, group learning, observational learning, and peer-to-peer learning.

- A place where accredited training is delivered.

- A place where local people offer training and there is local employment.

- The hub, the point of communication that streamlines training planning and delivery.

They found the key elements, critical to the success of the Learning Centre model include:

- Open access for all

- Desirable learning resources

- Good will

- An understanding that pathways to success require nurturing of confidence and selfesteem and essential, timely conversations

- Connections to the community

- 'Embeddedness' in the community and a broad sense of community ownership.

We consider these key elements in the following appraisal of the key elements of the Yuendumu Learning Centre.

\section{Flexibility and accessibility}

In terms of practical matters such as opening hours and access to computers and tutors, flexibility and accessibility were key elements. In providing both non-formal and formal learning (and training) as required, the Learning Centre was highly responsive.

A further powerful means of access to learning anywhere is language. As discussed above, the Learning Centre in Yuendumu is a bilingual space, where Warlpiri is both the natural code for learning and a valued cultural resource. Fostering bilingualism and language learning are important for access to learning. With a skilled adult LLN educator, the English language and literacy learning needs are understood and addressed in learning interactions, training planning and delivery. The importance of this expertise in adult learning delivery is noted elsewhere (Balatti, Black, \& Falk, 2009; Hunter \& Schwab, 1998; McRae-Williams, 2014).

The centre was a safe environment, where learners were encouraged to enrich and extend themselves through learning in their own style and pace. They could be self-directed and experimental in their learning, and pursue personal, practical and professional goals, short and long-term. In this way, learners are both controllers and producers of knowledge, and this gives rise to discovering passions and strengths, and crucial autonomy and agency in learning (Kral \& Schwab, 2012, pp. 69-73). It recognises the core of how learning is done - in 
situ, in achieving goals, drawing on resources, knowledge and experience from outside of the immediate learning interaction, through experimentation, trial and error and practice to mastery, and with others.

\section{A culture of learning}

The open-ended and diverse learning supported in the Learning Centre sets it apart from other sites. Here there is no obligation to take part, the value is intrinsic. As Kral and Schwab (forthcoming, p. 12) observe, in community learning centres, learning is a normal, sometimes useful, often essential, generally satisfying part of life. Learning is not something that is "owned" by others, it does not need to be measured or compared. It offers no threat, only value. But perhaps most significantly, they facilitate and validate a culture of learning. They create a place where learning is normal and valuable and for everyone. The impact of the public display of adult engagement in learning and literacy is powerful and transmits an important message to the next generation.

Role modelling learning practices is central to intergenerational uptake and reproduction. However, the culture of learning creates further roles and networks. As discussed earlier, the tutors at the Learning Centre expanded their roles and responsibilities as peers, mentors and facilitators, as their learning and mastery expanded. The development of roles and networks can be considered in capital theory terms, which sets social capital in 'networks of relationships [that] can facilitate access to other resources of value to individuals or groups for a specific purpose' (Balatti, Black \& Falk, 2009, p. 11). Learners achieve social capital outcomes as they experience changes 'in the way they interact with members of their existing networks and also the changes in the types and numbers of networks that they access or of which they become members' (Balatti, Black \& Falk, 2009). By taking part in a learning interaction, members of the community both entered and contributed to a network of learners. This leads to a further important element of the Learning Centre - the potential it has to create and nurture partnerships throughout the community.

\section{Community and partnerships}

The range of partnerships that Ros, as Learning Centre Co-ordinator was able to explore, negotiate and trial with individuals and organisations was a major strength of the Learning Centre. In the year the Learning Centre operated, local organisations such as WYDAC, the School, and the Shire office negotiated customised training and support. The training as trainers and learning facilitators for staff within organisations across the community provided through the Learning Centre (described in the section 'Spread the Learning' above) was particularly innovative, and made a significant contribution to improving the co-ordination of learning and training in the community. Wallace (2008) discusses learner identities and promotes the role of local experts as non-accredited facilitators and assessors, and the potential for local workplace-based accredited assessment via partnerships between educational institutions and local experts. This offers 'an opportunity to develop a shared understanding about the role of learning and connections between formal and informal learning' (p. 13). Such arrangements provide wide benefit as:

[I]earning partnerships have the potential to affirm everyone's identity as valued and essential participants in knowledge construction and expression. This can occur through the use of peer conversations and workplace-based action learning. (Wallace, 2008, p. 13) 
The contribution a learning centre can make in embedding learning and learning interactions in sites across the community is a further strength. This is an instance of the learning centre as a social asset, a repository and generator of social capital throughout a community.

\section{Building pathways}

With each new government, a raft of new employment policies and packages are rolled out in remote communities, rarely tailored or responsive to local histories, settings or aspirations. The pathway set is from individual unemployment to employment, sometimes with a crashcourse in work or employability skills. The success rate is low in terms of preparation for, or support into employment. Clearly both the training and its delivery along with motivation and engagement by trainees are crucial (Guenther, McRae-Williams \& Kilgariff, 2014). The learning centre model provides a locally responsive set of ways into learning, and learning for various purposes; social, civic and vocational. At Yuendumu, it offered a safe and flexible learning setting for entry to, and preparation for, employment. All of the tutors have followed through with employment goals they expressed when they began working at the Learning Centre.

\section{Future possibilities: Pathways beyond school}

In remote contexts, many education and training initiatives fail to take seriously the cultural distance and local aspirations and meet little success in long-term change (Osborne \& Guenther, 2013). Post-primary education has been limited in remote Indigenous communities in the Northern Territory historically, and secondary students have long been required to travel away to boarding schools and residential colleges to undertake secondary studies. However, few students remain in these facilities for the duration of secondary education and yet NT DoE has proposed reducing remote delivery of secondary schooling in remote locations in 2016, with all secondary learners to take up off-site options.

Currently at Yuendumu, the school offers a secondary program and WYDAC has re-engaged secondary learners, who do not attend the school program. Informal learning is providing those learners with opportunities, including Vocational Learning, particularly in Sport and Recreation, often coupled with employment in youth work (Shaw, 2015; Warlpiri Youth Development Aboriginal Corporation, 2013). There is scope for new partnerships, particularly given the commitment, expertise and funds invested in the Warlpiri Education and Training Trust. The role of the new Jaru Learning Centre may extend and adapt, with new opportunities and challenges, to meet local aspirations and goals for learning at Yuendumu.

\section{Challenges to community learning centres}

Two key challenges are discussed in this section; funding and staffing. During its year of operation, the Learning Centre was funded through the Warlpiri Triangle College NT DoE, in part through WYDAC's WELL program, and was able to generate additional funds through VET program delivery to outside organisations. Funding from NT DoE ceased with policy changes after the first year. The WETT Learning Centres operate in partnership with Batchelor Institute to oversee its operation, and their viability under this established remote training organisation may be well-served. However, Kral and Schwab (forthcoming) have discussed the challenges for learning centres where funding is directly linked to accredited training delivery. This pushes community learning centres towards a narrow model of delivery of centralised labour market and adult literacy programs. This tightly structured training has high monitoring and reporting demands on educators, leaving less time for individual learners or to support re-engaging learners. A key element of learning centres was flexible, responsive and meaningful learning, 
and there is a risk that such spaces lose the 'freedoms of time, space, activity and authority that [..] institutions rarely provide' (Heath \& Street, 2008, p. 5). Thus, funding streams to support re-engagement and non-formal learning are crucial.

Recruiting and retaining suitable staff in remote contexts poses a further challenge. Non-local staff are notoriously transient, and local staff are frequently mobile in the wider region. The skill set required for community learning centre co-ordinators extends beyond being a good LLN educator. Innovation, flexibility and preparedness to learn, work, and mentor others in a cross-cultural setting are needed. Promoting recruitment, training and empowerment of staff locally is also important for long term succession planning. In the shorter term, knowledgeable and authoritative community tutors can induct and guide new non-local staff. Many Warlpiri have a range of civil and family responsibilities, contributing to their mobility. Thus providing a number of flexible part-time positions is more responsive than recruiting to one fixed position.

\section{In conclusion}

The case study of the Yuendumu Learning Centre has revealed a dynamic learning place, with a range of learning, training and employment possibilities and uptake. However, this uptake is not automatic and rarely involves a seamless transition by an individual from school to employment. Overwhelmingly, residents at Yuendumu wish to stay and work in their community and seek the skills needed to do this. These aspirations were supported well by the Learning Centre during the research period. It provided a culturally safe place with flexibility to respond to individual and group needs. In contrast to education programs aimed at individual certification, the Learning Centre approach was holistic and placed-based. It provided expert support to learners and the wider community, and co-ordination and development of training opportunities. Thus it responded to Yuendumu as a learning community and made learning opportunities available by and for local people for local needs.

Future policy frameworks, including the 'Developing the North' program need to take notice of the great potential for community learning centres to support skill development and social enterprise with local Indigenous people, who have the greatest investment in this plan. This investment is not only social and cultural, given the financial commitment WETT has and continues to dedicate to community learning. The value of Indigenous languages, knowledge and local authority structures that already provide significant support to non-market services, such as clinics and schools, will increase in demand with any projected growth; and should be a part of this economic blueprint. A truly shared and inclusive vision would include the development of community learning centres in the Northern Territory in the northern development agenda.

\section{Acknowledgements}

We are grateful for the helpful comments provided by John Guenther on a previous draft of this paper.

The work reported in this publication was supported by funding from the Australian Government Cooperative Research Centres Program through the Cooperative Research Centre for Remote Economic Participation (CRC-REP). The views expressed herein do not necessarily represent the views of the CRC REP or Ninti One Limited or its participants. Errors or omissions remain with the author. We also wish to acknowledge Ninti One for providing the resources to fund this Special Issue as well as the Northern Institute, at Charles Darwin University for providing the opportunity for publication. 


\section{References}

Abbott, T. (2014). Statement to the House of Representatives - Closing the Gap. Retrieved from http://www.liberal.org.au/latest-news/2014/02/12/ prime-minister-statement-house-representatives-closing-gap-parliament-house.

Adult Learning Australia. (2014). Rethinking Community Based Learning. ALA Ltd.

Arnott, A. (2003). Learning from the past: implications for effective VET delivery of adult education services in the Northern Territory. Australian Journal of Adult Learning, 43(1), 43-72.

Australian Government. (2015). Our North, Our Future: White Paper on Developing Northern Australia. Canberra, ACT: Australian Government.

Australian Training Awards. (2013). Real Stories, Real Achievements. Retrieved from http://www. australiantrainingawards.gov.au/node/806.

Balatti, J., Black, S., \& Falk, I. (2009). A new social capital paradigm for adult literacy: Partnerships, policy and pedagogy. Adelaide, SA: National Centre for Vocational Education Research (NCVER).

Banks, J.A., Au, K.H., Ball, A.F., Bell, P., Gordon, E.W., Gutiérrez, K.D., Heath, S.B., Lee, C.D., Lee, Y., Mahiri, J., Nasir, N.S., Valdés, G., \& Zhou, M. (2007). Learning in and out of school in diverse environments: Life-long, Life-wide, Life-deep. Seattle, Washington: The LIFE Center and the Centre for Multicultural Education, University of Washington.

Barton, D., Hamilton, M., \& Ivanic, R. (2000). Situated Literacies: Reading and Writing in Context. London: Routledge.

Becker, G. (1993). Human Capital: A Theoretical and Empirical Analysis with Special Reference to Education. Chicago: University of Chicago Press.

Beddie, F., \& Halliday-Wynes, S. (2009). Informal learning: At a glance. Adelaide, SA: NCVER.

Berzins, B., \& Loveday, P. (1999). A University for the Territory: The Northern Territory University and Preceding Institutions 1949-1999. Darwin, NT: Northern Territory University.

Birch, E., Kenyon, P., Koshy, P., \& Wills-Johnson, N. (2003). Exploring the social and economic impacts of adult and community education. Adelaide, SA: NCVER.

Campbell, C., \& Proctor, H. (2014). A History of Australian Schooling. Sydney, NSW: Allen and Unwin.

Clemans, A. (2010). Stuck at home: A portrayal of educational work in community spaces, Studies in the Education of Adults. The National Institute of Adult Continuing Education (NIACE), 42(2), 156-169.

Collins, B. (1999). Learning Lessons: an independent review of Indigenous education in the Northern Territory. Darwin, NT: NT Department of Education.

Cope, B., \& Kalantzis, M. (2000). Multiliteracies: Literacy learning and the design of social futures. South Yarra, VIC: Macmillan.

Cushman, E., \& Emmons, C. (2002). Contact zones made real. In G. Hull \& K. Schultz (Eds.), School's out: Bridging out of school literacies with classroom practice. Columbia University New York: Teacher's College Press.

Disbray, S. (2014). Evaluating Bilingual Education in Warlpiri Schools. In R. Pensalfini, M. Turpin, \& D. Guillemin (Eds.), Language Description informed by Theory (pp. 25-46). John Benjamins.

Fordham, A., \& Schwab, R. (2007). Education, Training and Indigenous Futures. CAEPR Policy Research: 1990-2007 Centre for Aboriginal Economic Policy Research (pp. i-133). Canberra, ACT: Australian National University.

Frawley, J. (2003). Back to the future: Reflections of an adult educator. Ngoonjook, 23(Jul 2003), 44-51. 
Guenther, J. (2013). Are We Making Education Count in Remote Australian Communities or Just Counting Education? The Australian Journal of Indigenous Education, 42(2), 157-170.

Guenther, J. (2015). Analysis of National Test Scores in Very Remote Australian Schools: Understanding the Results through a Different Lens. In H. Askell-Williams (Ed.), Transforming the Future of Learning with Educational Research (pp. 125-143). Hershey, PA: Information Science Reference.

Guenther, J., \& Bat, M. (2013). Towards a Good Education in Very Remote Australia: Is it Just a Case of Moving the Desks Around? The Australian Journal of Indigenous Education, 42(2), 145-156.

Guenther, J., Disbray, S., \& Osborne, S. (2014). Digging up the (Red) Dirt on Education: One Shovel at a Time. Journal of Australian Indigenous Issues, 17(4), 40-56.

Guenther, J., Falk, I., Arnott, A., Lucardie, D., \& Spiers, H. (2008). Examining learning partnerships in northern Australia. Adelaide, SA: National Centre for Vocational Education Research.

Guenther, J., McRae-Williams, E., \& Kilgariff, C. (2014). Engineering Employment Pathways in Remote Communities and the (false) hope of Collaborative Service Provision. Paper presented at the NARU Public Seminar Series, Darwin. Retrieved from http://naru.anu.edu.au/_documents/ seminars/2014/john_guenther_collaboration_paper.pdf.

Gutiérrez, K.D. (2008). Developing a Sociocritical Literacy in the Third Space. Reading Research Quarterly, 43(2), 148-164. doi: 10.2307/20068336.

Gutierrez, K.D., \& Rogoff, B. (2003). Cultural Ways of Learning: Individual Traits or Repertoires of Practice. Educational Researcher, 32(5), 19-25.

Heath, S.B. (1991). The sense of being literate: historical and cross-cultural features. In R. Barr, M. L. Kamil, P. Mosenthal, \& P. D. Pearson (Eds.), Handbook of reading research, Volume 2. (pp. 3-25). New York and London: Longman.

Heath, S.B., \& Street, B. (2008). On ethnography: Approaches to language and literacy research (NCRLL volume). New York: Teachers College Press.

Hull, G. (2003). At last. Youth culture and digital media: New literacies for new times. Research in the teaching of English, 38(2), 229-233.

Hunter, B., \& Schwab, R. (1998). The determinants of Indigenous education outcomes Centre for Aboriginal Economic Policy Research (Vol. discussion paper no.60/1995, pp. iii-26). Canberra, ACT: Australian National University.

Kelly, L. (2011). 2010 Report on the Central Land Council Community Development Program. Alice Springs, NT: Central Land Council.

Kelly, L. (2015). 2014 Monitoring Report. Central Land Council Community Development Program. Alice Springs, NT: Central Land Council.

Knowles, M. (1980). The Modern Practice of Adult Education. Andragogy versus pedagogy. Englewood Cliffs: Prentice Hall/Cambridge.

Kral, I. (2010). Generational Change, Learning and Remote Australian Indigenous Youth. Canberra, ACT: Centre for Aboriginal Economic Policy Research, Australian National University.

Kral, I. (2012). Talk, Text and Technology. Literacy and Social Practice in a Remote Indigenous Community. Bristol: Multilingual Matters.

Kral, I., \& Falk, I. (2004). What is all that learning for? Indigenous adult English literacy practices, training, community capacity and health. Adelaide, SA: National Centre for Vocational Education Research.

Kral, I., \& Heath, S.B. (2013). The world with us: Sight and sound in the "cultural flows" of informal learning. An Indigenous Australian case. Learning, Culture and Social Interaction, 2, 227-237. 
Kral, I., \& Schwab, J. (2012). Learning Spaces: Youth, Literacy and New Media in Remote Indigenous Australia. Canberra, ACT: ANU E Press.

Kral, I., \& Schwab, R.G. (2009). Lifespan Learning and Literacy for Young Adults in Remote Indigenous Communities. Paper presented at the Youth Learning Symposium, Darwin.

Kral, I., \& Schwab, R.G. (in press). Meaningful learning, meaningful engagement, meaningful jobs: A community-based approach to adult learning in remote Indigenous Australia. Pedagogies.

Lave, J. (2011). Apprenticeship in Critical Ethnographic Practice. Chicago: University of Chicago Press.

Lincoln, S., Lynham, S., \& Guba, E. (2011). Paradigmatic controversies, contradictions, and emerging confluences, revisited. In N. Denzin \& Y. Lincoln (Eds.), The SAGE Handbook of Qualitative Research (4th Edition, pp. 97-128). Thousand Oaks: Sage Publications Inc.

McRae-Williams, E. (2014). Aspirations for meaningful livelihoods: Challenges of pathway navigation. Journal of Australian Indigenous Issues (Special Edition), 17(4), 57-71.

Mezirow, J. (2012). Learning to think like an adult: Core concepts of transformation theory. In E. Taylor, P. Cranton, \& Associates (Eds.), The Handbook of Transformative Learning: Theory, research and practice (pp. 73-96). San Francisco: Jossey Bass.

Musharbash, Y. (2008). Yuendumu Everyday. Canberra, ACT: Aboriginal Studies Press.

Northern Territory Department of Education. (1987). The Development of Community Education Centres in Aboriginal Communities in the Northern Territory. Darwin, NT: NT Department of Education.

Northern Territory Government. (2015). A Share in the Future: Indigenous Education Strategy 2015-2024. Retrieved from http://www.education.nt.gov.au/parents-community/ indigenous-education-strategy.

Osborne, S., \& Guenther, J. (2013). Red Dirt Thinking on Aspiration and Success. The Australian Journal of Indigenous Education, 42(Special Issue 02), 88-99. doi: 10.1017/jie.2013.17.

Patton, M. (2015). Qualitative research and evaluation methods: integrating theory and practice (4 $4^{\text {th }}$ Edition). USA: Sage.

Price, K. (2012). A brief history of Aboriginal and Torres Strait Islander education in Australia. In K. Price (Ed.), Aboriginal and Torres Strait Islander Education: An introduction for the teaching profession (pp. 1-20). Port Melbourne: Cambridge University Press.

Rogoff, B., Paradise, R., Arauz, R. M., Correa-Chavez, M., \& Angelillo, C. (2003). Firsthand learning through intent participation. Annual Review of Psychology, 54, 175-203.

Schwab, R. (1998). Educational 'failure' and educational 'success' in an Aboriginal community Centre for Aboriginal Economic Policy Research (Discussion paper no.161/1998). Canberra, ACT: Australian National University.

Schwab, R. (2006). Final Report to the Warlpiri Education and Training Trust Advisory Committee: Options for Education and Training. Alice Springs, NT: Central Land Council.

Shaw, G. (2015). 'There is a path'. An evaluation of the Warlpiri Youth Development Programs, incorporating the WETT (Warlpiri Education and Training Trust) Youth Development Program. Bowchung Pyt Ltd.

Stojanovski, A. (2011). Dog Ear Café. Australia: Port Campbell Press.

Van Manen, M. (1997). Researching Lived Experience. Canada: Althouse Press.

Wallace, R. (2008). Reluctant learners: Their identities and educational experiences (NCVER Occasional Paper). Adelaide, SA: Australia National Centre for Vocational Educational Research. 
Walton, C., \& Eggington, W. (Eds.). (1990). Language: Maintenance, Power and Education in Australian Aboriginal Contexts. Darwin, NT: Northern Territory University Press.

Warlpiri Education and Training Trust. (2013). The Warlpiri Education and Training Trust Story. Retrieved from http://www.clc.org.au/publications/content/the-warlpiri-education-and-training-trust-story.

Warlpiri Youth Development Aboriginal Corporation. (2013). Annual Report 2012/2013 Warlpiri Youth Development Aboriginal Corporation. Mt Theo, NT: Yuendumu.

Watson-Gegeo, K. (1992). A Thick explanation in the ethnographic study of child socialization: A longitudinal study of the problem of schooling for Kwara'ae (Solomon Islands) children. New Directions for Child Development, 58, 51-66.

Wenger, E. (1998). Communities of Practice. Learning, meaning and identity. Cambridge: Cambridge University Press.

Wilson, B. (2013). The Education Business: Review of Indigenous Education in the Northern Territory (Draft Report). Darwin, NT: Department of Education, Northern Territory Government.

Young, M., Guenther, J., \& Boyle, A. (2007). Growing the Desert: Educational pathways for remote Indigenous peoples. Adelaide, SA/Alice Springs, NT: National Centre for Vocational Education Research/Desert Knowledge Cooperative Research Centre. 
